\title{
Kualitas Pelayanan Pembuatan PASPOR PADA KANTOR IMIGRASI Kelas II TEMPAT PEMERIKSAAN IMIGRASI BIAK
}

jurnal.kemendagri.go.id/index.php/ $\mathrm{mp}$

e-ISSN: 2549-5283

p-ISSN: 2549-5151

Matra Pembaruan 4 (1) (2020):

37-46

DOI:-

10.21787/mp.4.1.2020.37-46

Keywords:Public Services, Passport Making, Policy, Local Government

Kata Kunci: Pelayanan Publik, Pembuatan Paspor, Kebijakan, Pemerintah Daerah

\section{${ }^{*}$ Korespondensi \\ Phone : +6282165706050 \\ Email : sukmawati22031997 \\ @gmail.com}

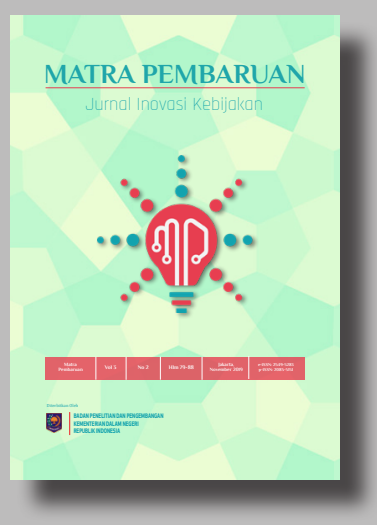

BADAN PENELITIAN DAN PENGEMBANGAN (BPP) KEMENTERIAN DALAM NEGERI

Jl. Kramat Raya No 132, Jakarta Pusat, 10450

(C)Sukmawati, Rijal, Hermanu Iriawan

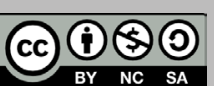

Karya ini dilisensikan di bawah Lisensi Internasional Creative Commons Atribusi Nonkomersial Sharealike 4.0.

\author{
Sukmawati ${ }^{{ }^{*}}$, Rijal $^{2}$, Hermanu Iriawan ${ }^{3}$ \\ 1,2,3 Institut Ilmu Sosial dan Ilmu Politik (IISIP) YAPIS Biak Papua \\ Jl. S. Condronegoro (Samofa) Biak-PAPUA
}

Dikirim: 09 September 2019; Direvisi: 03 April 2020;

Disetujui: 20 April 2020

\begin{abstract}
This research is motivated by the lack of quality level of service provided by employees and the lack of awareness of the applicant to prepare the documents that are required to conduct a passport-making service at the Class II Immigration Office Biak Immigration checkpoint. The purpose of this study is to find out, understand, study and describe the findings of researchers related to the quality of passport-making services at the Immigration Office Class II Biak Immigration Checkpoints using 5 service quality indicators namely tangible, responsiveness, realibility, assurance, and emphaty. The method used is a qualitative approach to the type of case studies, using data collection techniques namely observation, interviews, literature studies and documentation. Data types using primary data and secondary data. Location of the study was at the Class II Immigration Office, Biak Numfor Regency Biak Immigration Checkpoint. The results showed that the quality of passport-making services provided to the applicant has not been achieved properly and is maximally seen from the aspect of reliability where the system or network in the manufacture of passports is often hampered/interrupted and must wait until it can be reused. Seen from the aspect others such as tangible, responsiveness, assurance, and attention emphaty which has been reached to the maximum during the process of making a passport.
\end{abstract}

\section{Intisari}

Penelitian ini dilatarbelakangi oleh kurangnya tingkat kualitas pelayanan yang diberikan oleh pegawai dan kurangnya kesadaran pemohon untuk mempersiapkan berkas yang menjadi persyaratan untuk melakukan suatu urusan pelayanan pembuatan paspor pada Kantor Imigrasi Kelas II Tempat Pemeriksaan Imigrasi Biak. Tujuan penelitian ini adalah untuk mengetahui, memahami, mengkaji dan mendeskripsikan hasil temuan peneliti terkait kualitas pelayanan pembuatan paspor pada Kantor Imigrasi Kelas II Tempat Pemeriksaan Imigrasi Biak dengan menggunakan 5 indikator kualitas pelayanan yakni bukti langsung (tangibel), daya tanggap (responsiviness), keandalan (realibility), jaminan (assurance), serta perhatian (emphaty). Adapun metode yang dipakai adalah metode pendekatan kualitatif dengan jenis studi kasus, dengan menggunakan teknik pengumpulan data yaitu observasi, wawancara, studi kepustakaan dan dokumentasi. Jenis data dengan menggunakan data primer dan data sekunder. Lokasi penelitian di Kantor Imigrasi Kelas II Tempat Pemeriksaan Imigrasi Biak Kabupaten Biak Numfor. Hasil penelitian menunjukkan bahwa kualitas pelayanan pembuatan paspor yang diberikan kepada para pemohon belum tercapai dengan baik dan maksimal dilihat dari aspek keandalan (reliability) dimana sistem atau jaringan pada sangat pembuatan paspor masih sering terhambat/ gangguan dan harus menunggu sampai bisa digunakan kembali.Dilihat dari aspek lain seperti bukti langsung (tangible), daya tanggap (responsiveness), jaminan (assurance) dan perhatian (emphaty) yang sudah tercapai secara maksimal pada saat proses pembuatan paspor. 


\section{Pendahuluan}

Pelayanan publik sebenarnya merujuk pada pelayanan oleh pemerintah kepada masyarakat atau warga negera. Kurniawan, (2005, p. 4) menyatakan pelayanan publik merupakan istilah yang menggambarkan bentuk dan jenis pelayanan pemerintah kepada rakyat untuk kepentingan umum. Selain itu, pelayanan publik dapat diartikan sebagai pemberian layanan (melayani) keperluan orang atau masyarakat yang mempunyai kepentingan pada organisasi itu sesuai dengan aturan pokok dan tata cara yang telah ditetapkan. Senada dengan pernyataan di atas, Ratminto \& Winarsih (2005, p. 5) menyatakan, pelayanan publik atau pelayanan umum adalah segala bentuk pelayanan yang dilaksanakan oleh instansi pemerintah di pusat, daerah, dan lingkungan Badan Usaha Milik Negara atau Badan Usaha milik Daerah dalam bentuk barang atau jasa, baik dalam rangka upaya pemenuhan kebutuhan masyarakat maupun dalam rangka upaya pelaksanaan ketentuan peraturan perundang-undangan.

Mutu pelayanan publik di negara berkembang dewasa ini merupakan masalah yang sering muncul, umumnya permintaan akan pelayanan jauh melebihi kemampuan pemerintah untuk memenuhinya sehingga persoalan yang sering dikritisi masyarakat atau para penerima layanan adalah persepsi terhadap kualitas yang melekat pada seluruh aspek pelayanan. Karena itu pemerintah harus memberikan pelayanan terbaik kepada masyarakat.

UU No 25 Tahun 2009 tentang Pelayanan Publik menyatakan, perlayanan publik yang dilakukan oleh pemerintahan atau koporasi yang efektif dapat memperkuat demokrasi dan hak asasi manusia, mempromosikan kemakmuran ekonomi, kohesi sosial, mengurangi kemiskinan, meningkatkan perlindungan lingkungan, bijak dalam pemanfaatan sumber daya alam, memperdalam kepercayaan pada pemerintahan dan administrasi publik.

Pelayanan adalah pemberian jasa baik oleh pemerintah, pihak swasta atas nama pemerintah ataupun pihak swasta kepada masyarakat, dengan atau tanpa pembayaran guna memenuhi kebutuhan dan kepentingan masyarakat (Sagita, 2010). Tugas pelayanan masyarakat (public service) lebih menekankan kepada mendahulukan kepentingan publik, mempermudah urusan publik, mempersingkat waktu proses pelaksanaan urusan publik, dan memberikan kepuasan kepada publik.

Berbicara mengenai pelayanan, salah satunya yaitu pelayanan keimigrasian yang merupakan salah satu prioritas pelayanan publik yang dituntut untuk memberikan layanan yang prima, mengingat keimigrasian memiliki tugas dalam bidang perlintasan negara. Dalam keimigrasian, pelayanan pembuatan paspor merupakan yang sering kali dibutuhkan masyarakat. Pelayanan pembuatan paspor merupakan pelayanan yang memerlukan perhatian khusus, hal ini karena menyangkut dengan mobilitas masyarakat ketika akan pergi ke mancanegara. Selain itu, kebutuhan masyarakat akan kemudahan dalam mengurus dokumen perjalanan luar negeri atau paspor menjadi hal yang mutlak dalam pelayanan (Irawan, 2018, p. 1). Sehingga dengan akses yang mudah untuk membuat paspor juga akan memudahkan masyarakat untuk bermobilitas taraf internasional dan mendorong proses pembangunan melalui kerja sama.

UU No 9 Tahun 1992 Tentang Keimigrasian menjelaskan, setiap warga negara Indonesia berhak melakukan perjalanan ke luar atau masuk wilayah Indonesia. Selanjutnya pada pasal 3 dijelaskan bahwa setiap orang yang masuk atau ke luar wilayah Indonesia wajib memiliki surat perjalanan. Dapat disimpulkan bahwa masyarakat yang akan melakukan perjalanan ke luar Indonesia harus memiliki surat perjalanan yakni paspor. Sehingga di sini peran Kantor Imigrasi sebagai penyedia pelayanan publik berupa penerbitan paspor sangat penting.

Paspor adalah dokumen resmi yang dikeluarkan oleh pejabat yang berwenang dari suatu negara yang memuat identitas pemegangnya dan berlaku untuk melakukan perjalanan antar negara. Paspor berisi biodata pemegangnya yang meliputi antara lain foto pemegang, tanda tangan, tempat dan tanggal kelahiran, informasi kebangsaan dan kadang-kadang juga beberapa informasi lain mengenai identifikasi individual. Ada kalanya pula sebuah paspor mencantumkan daftar negara yang tidak boleh dimasuki oleh si pemegang paspor itu. Sebagai contoh, dahulu pemegang paspor Indonesia sempat dilarang berkunjung ke negara Israel dan Taiwan .

Paspor diperlukan untuk perjalanan internasional karena harus ditunjukkan ketika memasuki perbatasan suatu negara, walaupun di negara tertentu ada beberapa perjanjian di mana warga suatu negara tertentu dapat memasuki negara lain dengan dokumen selain paspor. Paspor akan diberi cap (stempel) atau disegel dengan visa yang dilakukan oleh petugas negara tempat kedatangan. Namun dalam pembuatan paspor ada saja kendala yang biasa terjadi sehingga pembuatan paspor harus di tunda, seperti yang telah dikemukanan oleh Kepala Seksi Lalu Lintas dan Izin Tinggal Keimigrasian Pada Kantor Imigrasi Kelas II Tempat Pemeriksaan Imigrasi Biak yang mengatakan bahwa pemeriksaan masih belum efektif dan masih harus dibenahi dalam hal sarana prasarana dan performance petugas.

Meskipun pihak lembaga telah berusaha untuk memberi kepuasan pelayanan publik yang baik dalam segala bidang, namun masih ada saja kendala yang dialami, seperti dalam proses pembuatan 
paspor masih sering terkendala oleh jaringan yang pada akhirnya dalam pembuatan paspor terhambat kerana semuanya masih tergantung pada sistem, yang akhirnya berdampak pada kualitas pelayananan. Hal ini merupakan suatu fenomena yang memberikan gambaran, manajeman pelayanan di lingkungan Kantor Imigrasi Kelas II Tempat Pemeriksaan Imigrasi Biak Kabupaten Biak Numfor terhadap kualitas pelayanan pembuatan paspor belum begitu efektif dikarena sistemnya terkadang mengalami gangguan dalam pembuatan paspor. Adapun Data Pelayanan Keimigrasian Pada Kantor Imigrasi Kelas II Tempat Pemeriksaan Imigrasi Biak Sebagai Berikut.

Tabel 1.

Data Pelayanan Keimigrasian Warga Negara Indonesia Tahun 2017-2019 Pada Kantor Imigrasi Kelas II TPI Biak

\begin{tabular}{ccc}
\hline No & Tahun & Jumlah \\
\hline 1. & 2017 & 1284 \\
\hline 2. & 2018 & 1095 \\
\hline 3. & $2019 / 5$ & 387 \\
\hline & Jumlah & $\mathbf{4 6 0 7}$
\end{tabular}

Sumber: Kantor Imigrasi Kelas II TPI Biak Tahun 2019

Pembuatan paspor Pada kantor imigrasi Warga Negara Indonesia (WNI) setiap tahunnya mengalami penurun yang bisa dilihat langsung dari table 1 diatas yang disebabkan karena minat masyarakat untuk membuat paspor ada setiap tahunnya memang berkurang.

Tabel 2.

Data Pelayanan Keimigrasian Warga Negara Asing Tahun 20172019 Pada Kantor Imigrasi Kelas II TPI Biak

\begin{tabular}{ccc}
\hline No & Tahun & Jumlah \\
\hline 1. & 2017 & 165 \\
\hline 2. & 2018 & 153 \\
\hline 3. & $2019 / 5$ & 6 \\
\hline & Jumlah & 320
\end{tabular}

Sumber: Kantor Imigrasi Kelas II TPI Biak Tahun 2019

Sama halnya dengan Pembuatan Paspor pada Kantor Imigrasi Warga Negara Asing (WNA) setiap tahunnya mengalami penurunan yang disebabkan oleh minat dan penolakan dalam pengajuan pembuatan paspor. Kualitas pelayanan (service quality) menjadi faktor yang menentukan dalam menjaga keberlangsungan suatu organisasi birokrasi pemerintah maupun organisasi perusahaan. Pelayanan yang baik dan sesuai dengan kebutuhan pengguna jasa publik, sangat penting dalam upaya mewujudkan kepuasan pengguna jasa publik (customer satisfaction) (Wahid et al., 2017, p. 375).

Wahid et al., (2017) juga mendefinisikan kualitas pelayanan secara sederhana, yaitu ukuran seberapa bagus tingkat layanan yang diberikan mampu sesuai dengan ekspektasi pelanggan. Artinya kualitas pelayanan ditentukan oleh kemampuan perusahaan atau lembaga tertentu untuk memenuhi kebutuhan yang sesuai dengan apa yang diharapkan atau diinginkan berdasarkan kebutuhan pelanggan/ pengunjung.

Fokus utama dari pelayanan publik di Indonesia adalah pemenuhan kebutuhan warga negara. Hal ini menunjukkan upaya serius penyelenggaraan pelayanan yang ditujukan kepada masyarakat sebagaimana yang diutarakan oleh Osborne \& Geabler (2005) yakni sebagai pemenuhan kebutuhan pengguna layanan bukan birokrasi penyelenggara pelayanan meeting the needs of costumer not the bureaucracy (Osborne \& Geabler, 2005). Setiap pelayanan publik memerlukan kejelasan informasi prosedur yang mudah dan tidak berbelit serta dibutuhkan usaha dari pemberi pelayanan agar dapat berjalan tertib dan lancer (Umam \& Ariyoso, 2019, p. 21). Berikut prosedur pelayanan pembuatan paspor pada Kantor Imigrasi Kelas II Tempat Pemeriksaan Imigrasi Biak :

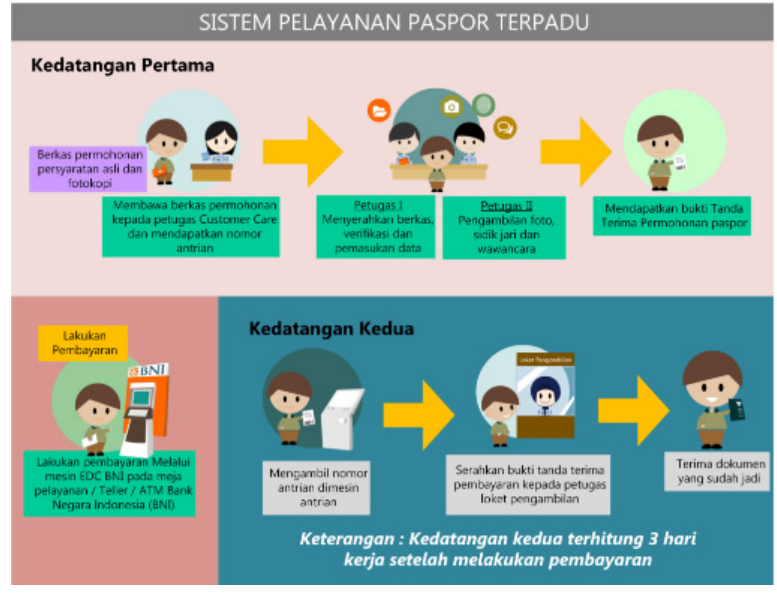

Gambar 1.

Prosedur Pembuatan Paspor Pada Kantor Imigrasi Kelas II Tempat Pemeriksaan Imigrasi Biak

Sumber: Kantor Imigrasi Kelas II TPI Biak Tahun 2019

Sebagaimana yang dikemukakan Rijal (2019, p. 50-51) bahwa pengaturan adalah suatu proses yang mengatur agar pembagian kerja dari berbagai orang atau kelompok dapat tersusun menjadi suatu kebutuhan yang terintegritas dengan cara efesien. Seperti contohnya petugas menerapkan sistem antri agar pelayanan dapat berjalan tertib. 
Unsur yang juga penting selain sistem, prosedur dan metode adalah unsur personel juga memiliki peranan penting dalam mewujudkan pelayanan yang baik. Unsur pendukung lainnya adalah sarana dan prasarana. Dengan tersedianya sarana dan prasarana yang lengkap, petugas juga akan mudah memberikan layanan. Unsur yang terakhir adalah masyarakat sebagai pengguna layanan. Masyarakat memunyai hak untuk mendapatkan pelayanan yang baik dari petugas pelayanan.

Tetapi selain memiliki hak, masyarakat juga mempunyai kewajiban untuk mematuhi prosedur pelayanan yang telah ditetapkan petugas agar terjadi keseimbangan hak dan kewajiban baik penerima layanan maupun pemberi layanan. Untuk menentukan kualitas pelayanan paspor di kantor imigrasi kelas II Tempat Pemeriksaan Imigrasi Biak, digunakan teori yang di kemukakan oleh Ratminto \& Winarsih (2005), yang terdiri atas 5 dimensi kualitas pelayanan yaitu: 1) Bukti Langsung (Tangible), yaitu: sebagai fasilitas yang dapat dilihat dan di gunakan perusahaan dalam upaya memenuhi kepuasan pelanggan, seperti gedung kantor, peralatan kantor, penampilan karyawan dan lain lain. 2) Keandalan (Reliability), yaitu: kemampuan memberikan pelayanan kepada pelanggan sesuai dengan yang di harapkan, seperti kemampuan dalam menempati janji, kemampuan memecahkan masalah dan kemampuan untuk meminimkan kesalahan. 3) Daya Tanggap (Responsiveness), yaitu sebagai sikap tanggap, mau mendengarkan dan merespon pelanggan dalam upaya memuaskan pelanggan, misalnya, mampu memberikan informasi secara benar dan tepat, tidak menunjukan sikap sok sibuk dan mampu memberikan pertolongan dengan segera. 4) Jaminan (Assurance), yaitu: kemampuan karyawan dalam menimbulkan kepercayaan dan keyakinan pelanggan melalui pengetahuan, kesopanan serta menghargai perasaan pelanggan. 5) Perhatian (Emphaty) yaitu: kemampuan atau kesediaan karyawan memberikan perhatian yang bersifat pribadi, seperti bersikap ramah, memahami kebutuhan dan peduli kepada pelanggannya.

Untuk mendukung permasalahan terhadap bahasan, peneliti berusaha melacak berbagai literatur dan penelitian terdahulu yang masih relevan terhadap masalah yang menjadi objek penelitian saat ini. Meskipun terdapat keterkaitan pembahasan, penelitian ini masih sangat berbeda dalam hal pokok isi pembahasan yang dibahas dan indikator yang digunakan pada setiap penelitian terdahulu dengan penelitian sekarang. Adapun beberapa penelitian terdahulu tersebut yaitu. Khusna (2013), yang meneliti Pelayanan Paspor di Kantor Imigrasi Kelas I Khusus Surabaya, dengan hasil penelitian bahwa pelayanan yang telah berjalan di Kantor Imigrasi Kelas I Khusus Surabaya berdasarkan perspektif dari Damampour. Di mana teknologi adanya proses produksi yang baru berupa
Intrenet apply system untuk melakukan permohonan paspor baik yang baru maupun yang perpanjang. Adapun perbandingan antara peneliti terdahulu, persamaannya terletak pada 5 Indikator yang digunakan dalam mengukur kualitas pelayanan. Sedangkan perbedaan dengan penelitian terdahulu adalah pada inovasi pelayanan paspor pada kantor imigrasinya, di mana peneliti terdahulu lebih terfokus untuk membahas bagaimana Inovasi yang digunakan dalam pelayanan pembuatan paspor atau perpanjangan paspor sedangkan peneliti sekarang membahas dan lebih terfokus untuk memahami dan mendiskirpsikan terkait kualitas pelayanan pembuatan paspor.

Denny dan Mustam (2017) menyimpulkan dalam hasil penelitiannya, masih kurang maksimalnya pelayanan yang dilakukan oleh Kantor Imigrasi Kelas I Semarang mengenai pelayanan pembuatan Paspor yang disebabkan oleh sistem yang berguna untuk menyimpan data pemohon paspor sering mengalami gangguan atau eror. Penelitiannya mempunyai fokus masalah yang sama yaitu terkait masalah Sistem atau jaringan dalam Pembuatan Paspor. Perbedaannya terletak pada indikator yang digunakan, di mana peneliti tmenggunakan Indikator interpersonel component, procedure enviroment, dan technical sedangkan penelitian ini menggunakan indikator bukti langsung (tangible), kehandalan (reliability), daya tanggap (responsiveness), jaminan (assurance) dan perhatian (emphaty).

Adapun penelitian ini mengungkap dan mendiskripsikan persoalan kualitas pelayanan yang berdampak langsung terhadap pembuatan paspor yang belum dilakukan secara optimal. Hal ini terjadi karena belum adanya Kehandalan (Reliability) yang menjadi salah satu indikator yang digunakan dalam mengukur kualitas pelayanan.

Kebaruan yang ditawarkan penilitan pada Kantor Imigrasi Kelas II Tempat Pemeriksaan Imigrasi Biak ini adalah tentang bagaimana bukti langsung, kehandalan, daya tanggap, jaminan dan perhatian dalam kualitas pelayanan yang diberikan kepada pemohon sehingga kendala dalam pemberian pelayanan tersebut baik yang menyangkut masalah sistem atau jaringan yang sering itu menjadi lebih baik lagi.

\section{Metode}

Penelitian ini dilakukan 3 bulan dari April s/d Juli 2019 yang berlokasi di Biak, Papua. Penelitian ini menggunakan metode Kualitatif. Metode penelitian ini dipilih untuk untuk memahami fenomena tentang apa yang dialami subyek penelitian. Juga dikatakan bahwa dalam penelitian kualitatif yang menjadi instrumen atau alat peneliti adalah peneliti itu sendiri. Oleh karena itu, peneliti sebagai instrumen juga harus divalidasi seberapa 
jauh peneliti kualitatif siap melakukan penelitian yang selanjutnya turun lapangan (Sugiyono, 2014, p. 59).

Jumlah informan sebanyak 11 orang. Di mana 11 infoman ini masuk dalam kategori yang mengetahui tentang bagaimana pelayanan pembuatan paspor dan bagaimana proses dalam pembuatan paspor seperti yang memberikan pelayanan pada Kantor Imigrasi dan Masyarakat yang Membuat Paspor pada Kantor Imigrasi. Adapun teknik pengumpulan data dengan menggunakan instrumen berupa yaitu Observasi, Wawancara dan dokumentasi.

Dalam menentukan Informan, peneliti melihat orang yang langsung memberikan pelayanan kepada para pemohon paspor, seperti pegawai pada Kantor Imigrasi tersebut dan sebagian informan juga dari masyarakat yang pernag membuat Paspor dan merasakan pelayanan secara langsung saat membuat Paspor. Hal tersebut dilakukan agar data yang diperoleh peneliti sifatnya objektif dan dapat dipertanggungjawabkan serta peneliti juga membaca, menelaah serta mempelajari dokumendokumen, buku-buku, jurnal atau literatur-literatur dan situs internet yang memiliki kaitan dengan topik penelitian.

Sumber data yang digunakan dalam penelitian ini ialah data primer yang dilakukan dengan cara observasi (pengamatan), dan interview (wawancara) yang diperoleh langsung dari 11 responden, dan data sekunder yang berupa buku-buku literatur, UU, dokumen-dokumen, jurnal, artikel serta situs di internet yang berkenaan dengan penelitian yang dilakukan.

\section{HASIL DAN PEMBAHASAN}

Pelayanan publik yang berkualitas menjadi salah satu tolok ukur untuk melihat apakah disuatu organisasi pemerintah (sektor publik) telah terjadi reformasi birokrasi. Sebagaimana yang dijelaskan oleh Iriawan dan Rizal (2019, p. 129), bahwa pelayanan publik diartikan sebagai upaya negara untuk memenuhi hak-hak dasar masyarakat dalam kapasitasnya sebagai warga Negara.

Pelayanan publik merupakan kegiatan atau rangkaian kegiatan dalam rangka pemenuhan kebutuhan pelayanan sesuai dengan peraturan perundang-undangan bagi setiap warga negara dan penduduk atas barang, jasa, dan/atau pelayanan administrasi yang disediakan oleh penyelenggara pelayanan publik (Fitriana, 2014, p. 1). Misalnya kesan miring yang muncul atas pelayanan publik yang dilakukan oleh sektor publik, tidak terlepas dari kenyataan, rendahnya kualitas pelayanan publik yang diberikan kepada masyarakat sebagai konsumen. Rendahnya pelayanan publik dimaksud, antara lain ditandai dengan: pertama, waktu pelayanan yang tidak jelas, sehingga masyarakat tidak dapat memprediksi kapan selesainya. Kedua, berbelit-belitnya pelayanan bahkan tidak jarang membuat masyarakat menjadi frustasi. Ketiga, dukungan sarana prasarana yang tidak memadai seperti komputer yang kadang bermasalah sehingga berdampak kepada pelayanan yang tidak optimal. Keempat, sumber daya manusia yang tidak responsif dalam memberikan pelayanan.

Pelayanan adalah proses pemenuhan kebutuhan melalui aktivitas orang lain yang langsung. Pelayanan dalam ensiklopedi administrasi diartikan sebagai suatu kegiatan yang dilakukan oleh organisasi maupun perseorangan untuk mengamalkan dan mengabdikan diri kepada masyarakat. Pelayanan merupakan aktivitas seseorang, sekelompok dan atau organisasi baik langsung maupun tidak langsung untuk memenuhi kebutuhan (Iriawan \& Rijal, 2019, p. 129). Pelayanan publik diharapkan mampu memberikan pelayanan yang dapat memenuhi dan memuaskan masyarakat. Pelayanan publik harus memperhatikan ketersedian sarana dan prasarana yang baik dan mampu melayani secara cepat dan tepat (Kasmir, 2011, p. 110).

Kualitas merupakan suatu kondisi dinamis yang berhubungan dengan produk, jasa, manusia, proses dan lingkungan yang memenuhi atau melebihi harapan (Tjiptono, 2012). Kualitas adalah kesesuaian dengan persyaratan, kecocokan untuk pemakaian, perbaikan berkelanjutan, bebas dari kerusakan/cacat, pemenuhan kebutuhan pelangggan sejak awal dan setiap saat.

Kualitas pelayanan pada masa kini menjadi permasalahan yang sering terjadi di setiap sektor publik. Hal ini ditandai dengan masih banyaknya berbagai keluhan masyarakat yang belum mendapatkan pelayanan secara optimal di media massa, sehingga dapat menimbulkan citra kurang baik terhadap aparatur pemerintah yang selaku pembuat pelayanan.

Pada dasarnya, terdapat beragam alat ukur, parameter, atau indikator kualitas layanan publik karena pihak yang menentukan kualitas beragam, berikut sudut pandangnya. Secara sederhana dapat dikatakan kualitas pelayanan dapat diketahui dengan cara membandingkan persepsi pelanggan atas pelayanan yang kenyataannya mereka terima atau peroleh dengan pelayanan yang sesungguhnya mereka harapkan atau inginkan. Jika kenyataan lebih dari yan diharapkan, maka pelayanan dapat dikatakan bermutu. Sedangkan jika kenyataannya kurang dari yang diharapkan, maka pelayanan dapat dikatakan tidak bermutu. Apabila kenyataan sama dengan harapan maka pelayanan tersebut memuaskan. Pelayananan publik akan memimiliki kualitas pelayanan yang tinggi apabila acuan utama penyelenggaranannya selalu berorientasi kepada pengguna jasa. Kepuasan pelanggan harus selalu mendapat perhatian dalam setiap penyelenggaranan pelayanan publik, karena merekalah penguasa 
yang memberikan pelayanan, merekalah berhak atas pelayanan yang terbaik diberikannya. Untuk acuan penyelenggaranan pelayanan publik harus senantiasa berorientasi pada kebutuhan masyarakat.

Kualitas pelayanan pembuatan paspor pada Kantor Imigrasi Kelas II Tempat Pemeriksaan Imigrasi Biak sudah semakin meningkat dalam hal memberikan pelayanan, seperti yang telah diungkapakan oleh ke 5 responden/ masyarakat yang sudah pernah membuat paspor Pada Kantor Imigrasi Kelas II TPI Biak. Meskipun memang harus masih dilakukan perbaikan karena masih sering mengalami kendala-kendala kecil dalam hal sarana dan prasarana dalam pelayanan. Tujuan utama dari perbaikan pelayanan tersebut semata-mata untuk mencapai kepuasan pelanggan. Oleh karena itu, perbaikan kualitas sebisa mungkin dilakukan secara terus menerus atau berkelanjutan sehingga bisa mencapai keberhasilan dan menjamin akan banyak pengunjung jasa keimigrasian.

Namun, dengan terus menerusnya perbaikan yang telah dilakukan ternyata masih belum dapat memberikan kepuasan terhadap pengguna jasa keimigrasian. Dengan citra pemerintah selama ini sebagai penyedia layanan publik sulit untuk memberikan kepuasan bagi pelanggan salah satunya pelayanan dalam pembuatan paspor yang selama ini sudah melekat di benak masyarakat bahwa salah satu bentuk yang penyelenggaraan pelayanannya yang buruk. Hal tersebut karena citra pelayanan yang mahal, lama, dengan prosedur yang berbelit-belit sudah sangat memasyarakat, sehingga kinerja pegawai pemerintahan khususnya Kantor Imigrasi dalam memberikan pelayanann yang terbaik haruslah ditingkatkan. Untuk perbaikan kualitas yang dilakukan Kantor Imigrasi dapat dilihat dengan banyaknya perbaikan, sarana dan prasarana, motivasi kerja, serta pengadaan fasilitasfasilitas yang mendukung di setiap tahunnya. Namun melihat background masyarakat pada bagian timur yang banyak berbeda sehingga mengakibatkan perbaikann-perbaikan yang dilakukan selama ini dapat dilakukan secara maksimal.

Untuk menentukan kualitas pelayanan paspor di Kantor Imigrasi Kelas II Tempat Pemeriksaan Imigrasi Biak, beberapa teori indikator kualitas pelayanan yang di kemukakan oleh Ratminto dan Winarsih (2010) yang mengemukakan bahwa ada 5 indikator untuk mengukur kualitas layanan adalah : 1) Bukti Langsung (Tangible), 2) Kehandalan (Reliability), 3) Daya Tanggap (Responsiveness), 4) Jaminan (Assurance), dan 5) Perhatian (Emphaty).

\section{A. Bukti Langsung (Tangible)}

Kualitas pelayanan pembuatan paspor di Kantor Imigrasi Kelas II Tempat Pemeriksaan Imigrasi Biak dilihat dari tangibles (bukti langung) yang ada masih apa adanya atau masih belum memenuhi standar kualitas pelayanan yang baik. Masih terdapat kekurangan dibeberapa bagian. Untuk bukti langsung dapat dilihat dari profil pelayanan yang ada, sarana dan prasarana yang mendukung dan performance petugas pelayanan yang ada. Ketiga elemen inilah yang menjadi bagian penting dalam memberikan pelayanan kepada masyarakat. Untuk ketiga fenomena yang berkaitan dengan tangibles tersebut hanya sarana dan prasarana yang dinilai sudah lengkap dan memadai dalam pelayanan, namun untuk profil pelayanan atau performance petugas yang dimiliki masih kurang karena masing-masing performance petugas berbeda-beda.

Tabel 3.

Sarana dan Prasarana Pada Kantor Imigrasi Kelas II TPI Biak

\begin{tabular}{|c|c|c|}
\hline No & Jenis Sarana dan Prasarana & Kuantitas \\
\hline 1 & Kendaraan Dinas & 10 \\
\hline 2. & Mesin Ketik Manual & 6 \\
\hline 3. & Mesin Fotocopy Folio & 1 \\
\hline 4. & Lemari Besi/Manual & 10 \\
\hline 5. & Lemari Kayu & 4 \\
\hline 6. & Rak Besi & 6 \\
\hline 7. & Filing Cabinet Besi & 8 \\
\hline 8. & Brandkas & 4 \\
\hline 9. & Buffet & 4 \\
\hline 10. & CCTV & 1 \\
\hline 11. & White Board & 8 \\
\hline 12. & Peta & 3 \\
\hline 13. & Display & 1 \\
\hline 14. & Server & 1 \\
\hline 15. & Laptop & 7 \\
\hline 16. & Printer & 19 \\
\hline 17. & Note Book & 1 \\
\hline 18. & PC Unit & 26 \\
\hline 19. & Finger Print & 2 \\
\hline 20. & Camera Digital & 4 \\
\hline 21. & Slide Projektor & 1 \\
\hline 22. & UPS & 8 \\
\hline 23. & Sound System & 1 \\
\hline 24. & Televisi & 5 \\
\hline 25. & Tape Recorder & 2 \\
\hline 26. & A.C. Split & 10 \\
\hline 27. & Lemari Es & 1 \\
\hline 28. & Mesin Pemotong Rumput & 1 \\
\hline 29. & Meja Komputer & 14 \\
\hline 30. & Alat Sidik Jari & 1 \\
\hline
\end{tabular}




\begin{tabular}{lll}
\hline 31. & Meja Kerja Kayu & 34 \\
\hline 32. & Kursi Besi Metal & 107 \\
\hline 33. & Sice & 29 \\
\hline 34. & Bangku Panjang Besi & 1 \\
\hline 35. & Bangku Panjang Kayu & 1 \\
\hline
\end{tabular}

Sumber: Kantor Imigrasi Kelas II TPI Biak

Bahkan untuk profil pelayanan Kantor Imigras belum memiliki media yang tepat agar masyarakat mudah dalam memahami dan mengakses setiap produk dan proses pelayanan yang ada. Selain itu, petugas yang berperan sebagai pelaksanan pelayanan yang ada juga masih kurang mendukung dalam memberikan pelayanan.

SDM yang terbatas saperti petugas yang memberikan pelayanan ketika mengalami kendalah dalam pembuatan paspor karena sistem dan pada ssat yang bersamaan banyak pemohon dalam pembuatan paspor membuat SDM-nya menjadi terbatas, yang saat itu tentunya membuat Kantor Imigrasi Kelas II Tempat Pemeriksaan Biak akan kewalahan dalam menangani permohonan yang begitu banyak dengan jangka waktu yang singkat yaitu 3 hari setelah pembayaran. Sehingga tidaklah mengherankan jika sering kali terjadi keterlambatan waktu seperti 5-10 hari sampai sistem bisa digunakan kembali dalam penyelesaian pembuatan paspor.

Selama ini, Kantor Imigrasi Kelas II Tempat Pemeriksaan Imigrasi Biak sendiri selalu berusaha memberikan perbaikan-perbaikan dalam saran dan prasarana pemenuhan kebutuhan bagi setiap pelanggannya. Adaya sarana yang disediakan seperti nomor antrian, lembaran persyaratan pembuatan paspor, kenyamanan ruang tunggu yang ber-AC, kelengkapan CCTV dan lainnya yang sangat membantu masyarakat dalam memperoleh pelayanan yang baik. Namun kelengkapan sarana pada Kantor Imigrasi Kelas II Tempat Imigrasi Biak masih ada yang tidak mendukung atau memadai seperti sosialisasi produk yang masih dilakukan melalui spanduk dan sosial media imigrasi saja.

Selain itu, produk layanan juga masih banyak yang belum dipahami masyarakat karena kebanyakan masyarakat hanya mengetahui mengenai paspor saja. Kurangnya informasi yang diketahui masyarakat karena kurangnya sosialisasi yang juga berkaitan dengan kurangnya SDM dalam memberikan pelayanan yang membuat mekanisme yang ada menjadi terhambat. Selain itu juga kurangnya informasi masyarakat terhadap pengoperasian fasilitas yang disediakan juga membuat penyediannya menjadi tidak efektif karena masyarakat cenderung tidak mau menggunakannya, dan kebanyakan masyarakat lebih memilih menggunakan mekanisme lain yang lebih mudah. Dan juga yang terlihat pada Kantor Imigrasi Kelas II tempat pemeriksaan imigrasi Biak itu adalah kurangnya data-data yang dibawah oleh pemohon sehingga menghambat proses pembuatan paspor.

Jadi dapat dinilai bahwa terkait kualitas pelayanan dilihat dari tangibles (bukti langsung) bahwa yang membuat pelayanan pembuatan paspor terhambat bukan hanya karena kurangnya sarana dan prasarana serta performance petugas namun juga karena ketersediaan berkas yang dibawah oleh pemohon yang tidak memenuhi persyaratan pembuatan paspor.

\section{B. Keandalan (Reliability)}

Kualitas pelayanan pembuatan paspor yang ada di Kantor Imigrasi Kelas II Tempat Pemeriksaan Imigrasi Biak juga dapat dinilai dari reliability (keandalan) petugas pelayanan yang ada. Dimensi ini terdiri dari keandalan petugas dan standar pelayanan yang dimiliki. Berdasarkan hasil penelitian yang dilakukan, maka peneliti memberikan penilaian terhadap dimensi ini kurang maksimal dilakukan pada kantor Imigrasi. Meskipun Kantor Imigrasi Kelas II Tempat Pemeriksaan Imigrasi biak telah memiliki SOP sebagai standar pelayanan yang digunakan sebagai acuan dalam pembuatan paspor, yang di mana sebelumnya hanya menggunakan kebijakan pimpinan sebagai pedoman. Dengan adanya SOP tersebut, maka petugas pelayanan memiliki target-target pencapain serta aturan-aturan yang ada.

Namun terkait kompotensi petugas pemberi pelayanan dalam meningkatkan kualitas pelayanan sudah sangat diusahakan memberikan yang terbaik, tetapi berdampak dari sistem atau jaringan yang selalu mengalami gangguan. Pemohon harus menunggu sampai sistem yang ada di pusat dikarenakan, sistem yang ada pada Kantor Imigrasi Kelas II Tempat Pemeriksaan Imigrasi Biak masih bergantung pada sistem yang ada di pusat. Jika sistem membaik barulah proses pembuatan paspor bisa dilakukan. Untuk itu diperlukan adanya pelatihan untuk mengatasi masalah-masalah yang ada dan bisa lebih mengoptimalkan dalam memberikan pelayanan.

\section{Daya Tanggap (Responsiveness)}

Kualitas pelayanan pembutana paspordi Kantor Imigrasi Kelas II Tempat pemeriksaan Imigrasi Biak juga dapati dinilai dari dimensi responsiveness (daya tanggap) petugas pelayanan. Dalam menganalisis hal tersebut dilakukan dengan melihat seberapa sering komplain terjadi terhadap pelayanan yang diberikan. Selain itu dengan melihat respons dan sikap petugas dalam dalam mengatasinya. Dimensi responsivenees atau daya tanggap petugas dalam pelayanan pembuatan paspor Kantior Imigrasi 
Kelas II tempat pemeriksaan Imigrasi Biak sudah cukup baik. Respons petugas juga sangat berkaitan dengan kompetensi yang dimiliki oleh petugas pelayanan. Dengan pengadaan pelatihan-pelatihan bagi setiap petugas tentunya akan membantu dalam membentuk daya tanggap petugas dalam menghadapi setiap pemohon maupun merespon segala yang menjadi kesulitan yang dirasakan oleh pemohon.

Dalam mekanisme pelayanan paspor, respons petugas dalam menangani juga harus cepat, selama masyarakat juga membantu dalam mekanisme yang sesuai dengan aturan atau persyaratan yang telah menjadi ketentuan. Untuk jaminan keamanan pada Kantor Imigrasi Kelas II Tempat Pemeriksaan Imigrasi Biak juga sudah cukup dikatakan baik, karena keamanan yang diberikan sudah sangat baik dirasakan oleh masyarakat. Pada Kantor Imigrasijuga tersedia kotak saran, masyarakat bisa memberikan atau menyampaikan keluhannya dengan penilaian puas, cukup puas dan tidak puas. Petugas Kantor Imigrasi juga selalu siap memberikan infromasi dan kekurangan-kekurangan apa saja yang masih perlu untuk dilengkap oleh pemohon agar pembuatan paspornya bisa di proses, selain itu petugas juga dinilai cukup baik dalam memberikan tanggapan dalam hal memeriksa dengan teliti berkas-berkas atau data-data para pemohon yang ingin membuat paspor.

\section{Jaminan (Assurance)}

Kualitas pelayanan pembuatan paspor di Kantor Imigrasi Kelas II Tempat Pemeriksaan Imigrasi Biak dapat juga dilihat dari assurance (jaminan) dalam pelayanan yang diberikan. Kejelasan tentang pelayanan pembuatan paspor dan mekanisme pelayanan pembuatan paspor, di mana masyarakat dengan sendirinya akan langsung datang ke Kantor Imigrasi maupun biro jasa dalam melakukan pelayanan. Dalam prosedur pembuatan paspor masih termasuk sulit untuk dipahami masyarakat meskipun pada awal ingin membuat paspor, ada lembaran dan penjelasan yang diberikan oleh petugas terkait persyaratan apa saja yang nanti akan dibawah pada saat ingin membuat paspor. Namun dikarenakan prosedur pembuatan paspor yang panjang dan membutuhkan waktu yang cukup lama untuk mengurusnya ketika ada kendala yang dialami bisa memakan waktu sampai 7-10 Hari. Untuk penyelenggaraan pelayanan pembuatan paspor selama ini sudah sesuai dengan prosedur yang ditetapkan. Dengan demikian dapat disimpulkan, tingkat kejelasan untuk pelayanan pembuatan paspor pada Kantor Imigrasi kelas II Tempata Pemeriksaan Imigrasi Biak sudah jelas dan baik.

Selain itu kepastian waktu jaminan untuk penyelesaian pelayanan pembuatan paspor yang ada masih belum begitu pasti atau jelas. Hal ini dapat diketahui dari kurangnya SDM sebagai pelaksana pelayanan, selain itu prosedur yang panjang dan kurang dipahami masyarakat yang sering menjadi penghambat karena terjadi beberapa masalah dalam proses dan teknisnya. Seperti sistem atau jaringan yang sering mengalami gangguan yang pada akhirnya membuat proses pembuatan paspor mengalami hambatan yang di mana ditetapkan, janji pelayanan paspor selesai 3 hari setelah pembayaran namun bisa menjadi lebih dari 1 minggu menunggu sampai sistem atau jaringan membaik kembali. Namun petugas Pada Kantor Imigrasi Kelas II Tempat Pemeriksaan Imigrasi Biak selalu berusaha dalam memberikan kepuasan dan tidak mengecewakan pemohon dan sebisa mungkin selalu memberikan arahan yang mudah dimengerti oleh para pemohon selama proses pembuatan paspor berlangsung.

\section{E. Perhatian (Emphaty)}

Kualitas Pelayanan Pembuatan Paspor di Kantor Imigrasi Kelas II Tempat Pemeriksaan Imigrasi Biak juga dapat dilihat dari dimensi emphaty (perhatian) yang menjadi pusat paling utama dalam pelayanan pembuatan paspor yaitu terkait dengan keramahan dan kesopanan petugas pemberi pelayanan. Pembuatan paspor pada Kantor Imigrasi ini sudah dikatakan ramah dan sopan dalam penyelenggaraan pelayanan pembuatan paspor yang dilakukan selama ini.

Hal itu dibuktikan dengan keterangan dari beberapa pemohon yang sudah menerima pelayanan dan telah selesai dalam membuat paspor. Baik tidaknya perlakuan yang diberikan petugas terhadap masyaraka dapat dijadikan tolok ukur dalam memenuhi kepuasan pemohon. Petugas yang ada di Kantor Imigrasi Kelas II Tempat Pemeriksaan Imigrasi Biak selalu berusaha dalam memahami kebutuhan dari setiap pelanggannya, petugas juga selalu berusaha memberikan rasa kepedulian terhadap pemohon yang betul-betul membutuhkan paspor yang harus diselesaikan sesegera mungkin, dan mampu untuk mengatasi kendala-kendala yang dialami pemohon pada saat membuat paspor.

\section{KESIMPULAN}

Berdasarkan hasil penelitian yang dilakukan pada kantor Imigrasi terkait kualitas pelayanan dalam pembuatan paspor dapat disimpulkan bahwa ke 5 dimensi dalam kualitas pelayanan dalam pembuatan Paspor di Kantor Imigrasi Kelas II Tempat Pemeriksaan Imigrasi Biak belum tercapai secara maksimal hal ini terlihat dari aspek : Dimensi keandalan (reliability) yaitu staff pada kantor imigrasi harus selalu berusaha memberikan pelayanan kepada pemohon sesuai dengan yang di harapkan, dan mampu untuk menempati janji, memecahkan masalah meskipun terkadang proses pembuatan paspor tidak sesuai dengan janji layanan 
yaitu 3 hari setalah pembayaran dikarenakan sistem atau jaringan yang terkadang gangguan.

Kualitas pelayanan pada aspek lainnya sudah tercapai secara maksimal yaitu (1) Dimensi bukti langsung (tangible) di mana terkait fasilitas sarana yang digunakan dalam pembuatan paspor sudah cukup memadai yang mampu untuk memperlancar dan memudahkan dalam proses pembuatan paspor. (2) Dimensi daya tanggap (responsiveness) sudah dilakukan dengan baik antara staff dan pemohon yang di mana staff selalu siap memberikan infromasi dan kekurangan-kekurangan apa saja yang masih perlu untuk dilengkap oleh pemohon agar pembuatan paspornya bisa di proses, di mana petugas dalam pelayanan harus memiliki sikap cepat tanggap, mau mendengarkan dan merespon pemohon dalam upaya memuaskan pemohon. Seperti kemampuan petugas dalam membantu masyarakat yang bermasalah dengan pelayanan dan keluhan, serta ketersediaan wadah untuk menampung aspirasi, saran dan keluhan dari masyarakat, mampu memberikan informasi secara benar dan tepat, tidak menunjukkan sikap sok sibuk dan mampu memberikan pertolongan dengan segera.

Kemudian (3) dimensi jaminan (assurance) juga sudah dilakukan dengan baik, dimana staff harus mampu memberikan rasa kepercyaan dan selalu memberikan arahan yang mudah dimengerti oleh para pemohon selama proses pembuatan paspor berlangsung yang akan membuat pemohon merasa lebih dihargai lagi ketika membuat paspor pada kantor Imigrasi Biak. Serta (4) Dimensi perhatian (empaty) yang juga telah dilakukan dengan baik antara staff dengan pemohon dimana staff selalu berusaha memberikan rasa kepedulian terhadap pemohon yang betul-betul membutuhkan paspor jadi sesegera mungkin, dan mampu mengatasi kendala-kendala yang dialami pemohon dan tanpa membedah-bedahkan pemohon yang ingin membuat paspor.

Faktor Pendukung dalam pelayanan pembuatan paspor pada kantor Imigrasi Kelas II Tempat Pemeriksaan Imigrasi Biak adalah fasilitas sarana dan prasarana yang sudah terlaksana secara optimal. Dengan adanya fasilitas pendukung dalam kantor Imigrasi tersebut seluruh kegiatan maupun pekerjaan yang dibebankan kepada petugas menjadi lebih mudah dan lancar.

Faktor Penghambat dalam pelayanan pembuatan paspor pada kantor Imigrasi Kelas II Tempat Pemeriksaan Imigrasi Biak adalah disebabkan juga oleh kurangnya kesadaran masyarakat dimana kesadaran masyarakat dimaksudkan ialah kesadaran untuk mempersiapkan segala yang menjadi persyaratan untuk melakukan suatu urusan pelayanan di Kantor Imigrasi Kelas II Tempat Pemeriksaan Imigrasi Biak, di mana relasi antara petugas dengan pemohon paspor memang harus saling mendukung agar dapat mencapai tujuan yang di harapkan, baik itu dari pihak masyarakat maupun dari pihak petugas itu sendiri.

\section{UCAPAN TERIMA KASIH}

Ucapan terima kasih penulis ucapkan kepada Djamil Hasim selaku Rektor IISIP Yapis Biak dan civitas Akademik IISIP Yapis Biak serta segenap Pegawai Kantor Imigrasi Kelas II Tempat Pemeriksaan Imigrasi Biak. Terima Kasih saya ucapakan kepada Ibu Siska Sawor yang telah membantu dalam penyelesaian artikel penelitian ini.

\section{Daftar Pustaka}

Denny, \& Mustam, M. (2017). Kualitas Pelayanan Pembuatan Paspor di Kantor Imigrasi Kelas I Semarang. Journal of Public Policy and Management Review, 6(1), 1-8. https://doi. org/10.14710/jppmr.v1i1.14500

Fitriana, D. N. (2014). Inovasi Pelayanan Publik BUMN(Studi Deskriptif tentang Inovasi Boarding Pass System dalam Meningkatkan Kualitas Pelayanan Kereta Api PT KAI di Stasiun Gubeng Surabaya). Kebijakan Dan Manajemen Publik, 2(1), 1-10. http://www. journal.unair.ac.id/download-fullpaperskmp3c8840fbddfull.pdf

Irawan, A. (2018). Transparansi Pelayanan Publik Pada Dinas Penanaman Modal Dan Pelayanan Terpadu Satu Pintu (DPMPTSP) | Madani Jurnal Politik dan Sosial Kemasyarakatan. Madani; Jurnal Politik Dan Sosial Kemasyarakatan, 10(3), 86-101. http://e-jurnal.unisda.ac.id/ index.php/MADANI/article/view/1266

Iriawan, H., \& Rijal. (2019). Reformasi Birokrasi dalam Pelayanan Publik ( Studi Kasus UPTB Samsat Kabupaten Biak Numfor ). Kolaborasi : Jurnal Administrasi Publik, 5(2), 128-141. https://doi.org/10.26618/kjap.v5i2.2290

Kasmir. (2011). Etika Customer Service (Rajawali P).

Khusna, K. (2013). Kajian Kebijakan Inovatif Bidang Pelayanan Terpadu Satu Pintu Penanaman Modal /Investasi di Indonesia. Jurnal Forum Ilmu Sosial Dan Humaniora, 1(1), 21-30. https://journalfishum.ypps-uts.ac.id/fishum/ index.php/JFISHUM/article/download/3/3

Kurniawan, A. (2005). Transformasi Pelayanan Publik. Pembaruan.

Osborne, D., \& Geabler, T. (2005). Mewirausahakan Birokrasi: Menstransformasi Semangat Wirausaha ke Dalam Sektor Publik (cet. 4). Pustaka Binaman Pressindo.

Ratminto, \& Winarsih, A. S. (2010). Manajemen Pelayanan. Pustaka Pelajar. 
Rijal, R. (2019). Koordinasi Dinas Perhubungan dan Satuan Lalu Lintas dalam Penanggulangan Kemacetan Kota Makassar. Matra Pembaruan, 3(1), 47-56. https://doi.org/10.21787/ mp.3.1.2019.47-56

Sagita. (2010). Peran Kualitas Pelayanan Pelanggan Tentang Prosedur Pemasangan Jaringan Baru dan Perubahan Daya Listrik PT PLN (Pesero) Area Pelayanan Jaringan Surabaya Selatan. Pepustakaan STIKOM Surabaya.

Sugiyono. (2014). Metode Penelitian Kuantitatif Kualitatif dan R\&D (Sugiyono (ed.); 2014th ed.). Alfabeta.
Tjiptono, F. (2012). Strategi Pemasaran (Edisi Kedu). Andi.

Umam, K., \& Ariyoso, D. (2019). Manajemen Kinerja Kementerian Sekretariat Negara dalam Mengelola Pelayanan Informasi Publik. Ministrate: Jurnal Birokrasi Dan Pemerintahan Daerah, 1(1), 19-38. https:// doi.org/10.15575/jbpd.v1i1.6312

Wahid, U. T., Azikin, R., \& Ma'ruf, A. (2017). Kualitas Pelayanan dalam Pengurusan Paspor di Kantor Imigrasi Kelas I Makassar. Kolaborasi : Jurnal Administrasi Publik, 3(3), 373-388. https:// doi.org/10.26618/kjap.v3i3.1059 